\title{
EDITORIAL
}

\section{Desde los derechos derivados a los derechos propios: hacia las pensiones propias de las mujeres}

Eva M. BlázQuez Agudo

Universidad Carlos III de Madrid

doi: http://dx.doi.org/10.20318/femeris.2016.3223

En general, en el ámbito contributivo de las prestaciones de la Seguridad Social coincide el sujeto que genera el derecho, a través de sus cotizaciones, y el beneficiario de la ayuda. No obstante, esta regla se rompe en el contexto de las prestaciones de muerte y supervivencia, donde hay que diferenciar entre quien contribuye al sistema y genera el derecho, y quien lo percibe por su relación familiar y/o dependencia con el primero. De este modo, se vincula el beneficio al hecho de ser hijo, pariente o estar casado o vivir como pareja de hecho de alguien. Así, dichas pensiones han sido tradicionalmente reguladas como derechos derivados que tienen los familiares a la muerte de un pariente del que hasta este momento dependían económicamente.

En especial, la pensión de viudedad se ha regulado históricamente como un derecho derivado, ya que su concesión se ha basado en la relación conyugal con el causante de la prestación. Esta protección ha sido recientemente extendida a los miembros de las parejas de hecho, siempre que cumplan ciertas condiciones.

La construcción de la pensión de viudedad en la Orden de 13 de febrero de 1967 se realizó sobre una realidad social determinada: la mujer permanecía en casa al cuidado de la familia, mientras que el marido trabajaba fuera de hogar, proveyendo a la familia de los recursos económicos necesarios para su subsistencia. Con lo cual era lógico que al fallecer éste último se garantizará un medio de vida a quienes hasta ese momento habían dependido económicamente del causante. Es por esto que no fue hasta 1990 cuando la ley reconoció el acceso a la pensión de viudedad de forma general y en iguales condiciones a los viudos que a las viudas. Hasta ese momento solo se reconocía el derecho a los viudos que demostrasen su incapacidad para el trabajo y su dependencia de su esposa fallecida, condiciones que no se demandaban a las viudas, ya que se presumía que ellas sí cumplían ambos requisitos. 
Aunque desde ese momento se exigen idénticos requisitos de acceso a la pensión de viudedad para hombres y para mujeres, sin embargo, han sido las viudas quienes han seguido beneficiándose mayoritariamente de dicha prestación (Según datos del MESS, a 1 de junio de 2016 hay 2.181.184 mujeres frente a 176.958 hombres percibiendo la pensión de viudedad). Como fácil se deduce, el patrón de la sociedad anterior extiende sus consecuencias aún hoy en día, sobre todo respecto a los ciudadanos mayores de 50 años, que son el colectivo que tienen más probabilidades de acceder al beneficio. Así, la mayoría de los hombres han trabajado y cotizado y, por tanto, consecuentemente son los causantes de la pensión, mientras que las mujeres no han contribuido al sistema y son muy pocas las que han originado la prestación a favor de sus cónyuges. Además a esta realidad se añade otra desde el ámbito del análisis de las cifras sobre esperanza de vida: las mujeres viven más que los hombres, con lo cual hay en general hay un mayor número de viudas que de viudos.

En definitiva, aún todavía los hombres acceden mayoritariamente a pensiones propias (la pensión de jubilación), ya que han cotizado lo suficiente para ello; y las mujeres perciben pensiones derivadas (las pensiones de viudedad). En este contexto, no hay que olvidar que las pensiones mínimas son inferiores en el segundo supuesto y, en general, también su cuantía media, lo que influye directamente en la feminización de la pobreza (la pensión media de jubilación de los hombres es de 1210, 91 euros frente a la pensión de viudedad media de las mujeres que es de 650,44 euros).

Frente a esta situación provocada por los efectos de la anterior realidad social, hay que pensar que ahora la mujer, en mayor o menor medida, se está incorporando al mercado laboral y en el futuro es esperable el aumento del número de beneficiarias de la pensión de jubilación y la generación por estas de pensiones de viudedad para sus cónyuges o parejas de hecho varones. Este panorama llevará probablemente a que el legislador reconstruya este derecho, incompatibilizando pensión de jubilación (o en su caso renta de trabajo) con pensión de viudedad. Si este ocurre, las prestaciones de viudedad solo se concederán a aquellas personas, mayoritariamente mujeres, que no hayan cotizado lo suficiente para acceder a la jubilación, puesto que en general siguen siendo ellas quien aún permanecen al cuidado hogar. Desde estas premisas, se concluirá que las pensiones de viudedad seguirán feminizadas en idéntico sentido que en la actualidad, aunque debido a otra realidad social, aunque seguramente se reducirá su número exponencialmente si se incompatibilizan jubilación-viudedad, puesto que es previsible que cada vez más mujeres accedan a la pensión de jubilación.

Enmarcados en este contexto, desde aquí se reivindica que los ciudadanos no deben ser protegidos por ser cónyuge o pareja de hecho de otro, sino que deben ser atendidos a través del reconocimiento de derechos propios. Algunos sistemas europeos de Seguridad Social, aportan ejemplos de cómo se podría regular esta actuación: en Francia se establece una prestación que consiste en atribuir, bajo condición de prueba de carencia de recursos, cierta forma de aseguramiento en la vejez, a las personas que no ejercieron actividad profesional por dedicarse al cuidado de sus hijos (assurance-viellesse des parent au foyer). Otra opción sería la del derecho alemán que contempla el traspaso de cuotas desde el consorte trabajador al cónyuge que no ha realizado actividad laboral por dedicarse al cui- 
dado directo de la familia, lo que lleva a este último a adquirir las prestaciones de vejez por derecho propio.

La Ley 40/2007, de 4 de diciembre, que incluyó importantes modificaciones en las principales pensiones, ya anunció la necesidad de repensar la pensión de viudedad adaptándola a las nuevas necesidades sociales, sobre todo en relación a los nacidos después de 1967. Si finalmente se desarrolla esta disposición es esperable que se incompatibilice la posibilidad de beneficiarse de la pensión de jubilación, de esta forma solo se concederá la viudedad a quienes no hayan cotizado lo suficiente. No obstante, se entiende que para este colectivo sería más adecuado buscar fórmulas para reconocerles derechos propios partiendo de su carencia de rentas y de su aportación a la sociedad a través del cuidado de sus hijos o familiares. En definitiva, fuera de la protección contributiva, constituyendo prestaciones de corte asistencial concedidas de acuerdos con sus propias situaciones.

Obviamente esto implicaría la desaparición de la pensión de viudedad, pero no la desprotección de este colectivo ahora atendido por dicho beneficio, dado que se pasaría a concederles otras protecciones vinculadas a sus propias características y no a sus relaciones conyugales o de convivencia. En todo caso, solo parece adecuado llevar a cabo esta reforma en relación a las mujeres menores de 50 años, dado que las mayores de esta edad han vivido en otra realidad social, donde los roles de la familia estaban preestablecidos y hay razones para defender que se mantenga su atención en el sentido esperado por las propias beneficiarias.

Para finalizar es importante realizar en este asunto una aclaración. Hasta el momento se ha tratado el tema desde el punto de vista de las mujeres que acceden a la pensión de viudedad desde la pensión de jubilación de sus maridos o convivientes, pero no se puede olvidar la realidad de los progenitores que quedan solos a cargo de sus hijos al fallecimiento del otro. Si en el futuro la legislación prohíbe la compatibilidad entre pensión de viudedad y renta de trabajo, el acceso a prestaciones propias puede ser insuficiente para mantener económicamente el hogar; pero, incluso está situación puede ser similar cuando el progenitor deba mantener solo con sus rentas a sus familias, cuando hasta ese momento habían sido dos los sustentadores de ese núcleo. Es por esto que en este contexto parece que la única solución es reconocer pensiones de orfandad económicamente suficientes para el sostenimiento de los hijos, lo cual hay razones para defender como factible en el supuesto que no sea preciso abonar el porcentaje señalado para la pensión de viudedad y se pueda dedicar a proteger a los hijos. 